\title{
ANALYSIS OF ROAD INTERVENTION BASED ON GEOGRAPHICAL ACCESSIBILITY AS A DEVELOPMENT TOOL IN REGIONAL COMPETITIVENESS
}

\author{
Jorge MONTOYA, Diego ESCOBAR, Jorge GALINDO \\ Universidad Nacional de Colombia, Manizales, Columbia
}

\begin{abstract}
Regional transport connectivity plays an important role in economic and productive development; hence, a good transport infrastructure fosters profit-making competitiveness, and it improves the quality of life of the population. In this research, the objective is to analyze the impact on road transport costs and the number of possible trips from road infrastructure interventions to improve the connectivity and competitiveness of the municipality of Tumaco (Colombia) in the region. The study methodology is based on the concept of geographical accessibility, supported by using GIS-type applications, which allows evaluating the access conditions of the study area, based on the characteristics offered by the road network. From the analysis, our results show that it is possible to achieve a reduction in the costs per ton of up to $7.53 \%$ and an up to $10.23 \%$ increase in the number of possible trips. The main conclusion is that geographical accessibility models give a much broader vision on the impact generated by road interventions. Therefore, they could be included in the constructive evaluation of development projects.
\end{abstract}

Key Words: road infrastructure, transport, accessibility, regional studies, connectivity.

\section{Introduction}

Transport infrastructure is currently part of the backbone of economic and social development ( $\mathrm{Li}$ and $\mathrm{Qi}, 2016$, Skorobogatova and Kuzmina-Merlino 2017), allowing the communication and development of activities in the context of globalization (Pike et al. 2017), which guarantee a higher quality of life. However, this development influenced by transportation is directly linked to the costs, generating strong questions as a factor of location and competition at local and interregional level (Fujita et al. 1999, Fujita and Thisse 2002). In this sense, if adequate infrastructure interventions are carried out, it is possible to obtain reductions in the input costs and therefore improvements in productivity and competition. Considering the above, transport connectivity and evaluation processes facilitate decision-making by the government entities, characterizing which intervention would be the most efficient, as well as the benefits obtained from the intervention. Therefore, in the present research, the authors proposed to carry out a regional analysis of road transport connectivity, based on the costs and possible trips, with a focus on the municipality of San Andrés de Tumaco, Columbia, formulating two possible interventions as an active measure to improve the competitiveness of the municipality in the region. It is important to clarify that the study area is selected based on the general research project associated with the Colciencias 812 call for proposals as a measure to support peacebuilding.

Regarding the evaluation dynamics to be used, an analysis of costs and the number of possible trips is proposed based on a geographical accessibility approach; one that visualizes the impacts from the different interventions carried out (geometric correction, repaving surface, increase speed) (Cui and Levinson 2018), which should result in greater ease for decision-making by the local or regional leaders. Accessibility, from a general point of view, has a wide range of definitions, in which the ability of people to access certain distributed activities is considered as an inherent advantage of one place over another (Ingram 1971), or the capacity of activities to attract people (Curl et al. 2011, Rubulotta et al. 
2013). However, any technical definition is based on the definition established by Hansen (1959), which considers accessibility as the potential of opportunities for interaction. However, giving a more consistent view of the research, we will define accessibility as a measure of the spatial or temporal separation of human activities, from a transport system (Morris et al. 1979), subject to limitations for them to be achieved given the existence of barriers (Geurs and Van Wee 2004, Vega 2011). This definition extends the terminology a little more, in which only the places are considered and not how people travel. Some applications of accessibility in various fields pose it in residential terms (Elldér 2014), social exclusion (Grengs 2015, Vitale Brovarone and Cotella 2020), transportation costs (Cui and Levinson 2018), transportation planning (Handy and Niemeier 1997), demographic analysis (Kotavaara et al. 2011), and sustainability (Vega 2011), among others.

\section{Methodology}

\section{Study area}

San Andrés de Tumaco is located in the southwestern strip of Columbia, on the Pacific Ocean shore (Fig. 1), over $1^{\circ} 48^{\prime} 24^{\prime \prime}$ North latitude and $78^{\circ} 45^{\prime} 53^{\prime \prime}$ West longitude. It belongs to the Nariño Department and it has a total extension of $3591.16 \mathrm{~km}^{2}$ (Tumaco District Mayor's Office 2017), in which 212692 inhabitants reside (DANE 2018). Tumaco has an average elevation of 1 m.a.s.l. and a temperature of $26^{\circ} \mathrm{C}$ on average, which facilitates productivity concerning the African palm, cocoa, coconut, and fishing on the seashore (Tumaco District Mayor's Office 2017). These agricultural activities make up the main economic contribution of the municipality $(83 \%)$, which generates an added annual value of 371706947.61 USD (DANE 2019), which gives it a national importance rating of 3 units, 1 being the best rating and 7 the most unfavourable condition (DANE 2019).
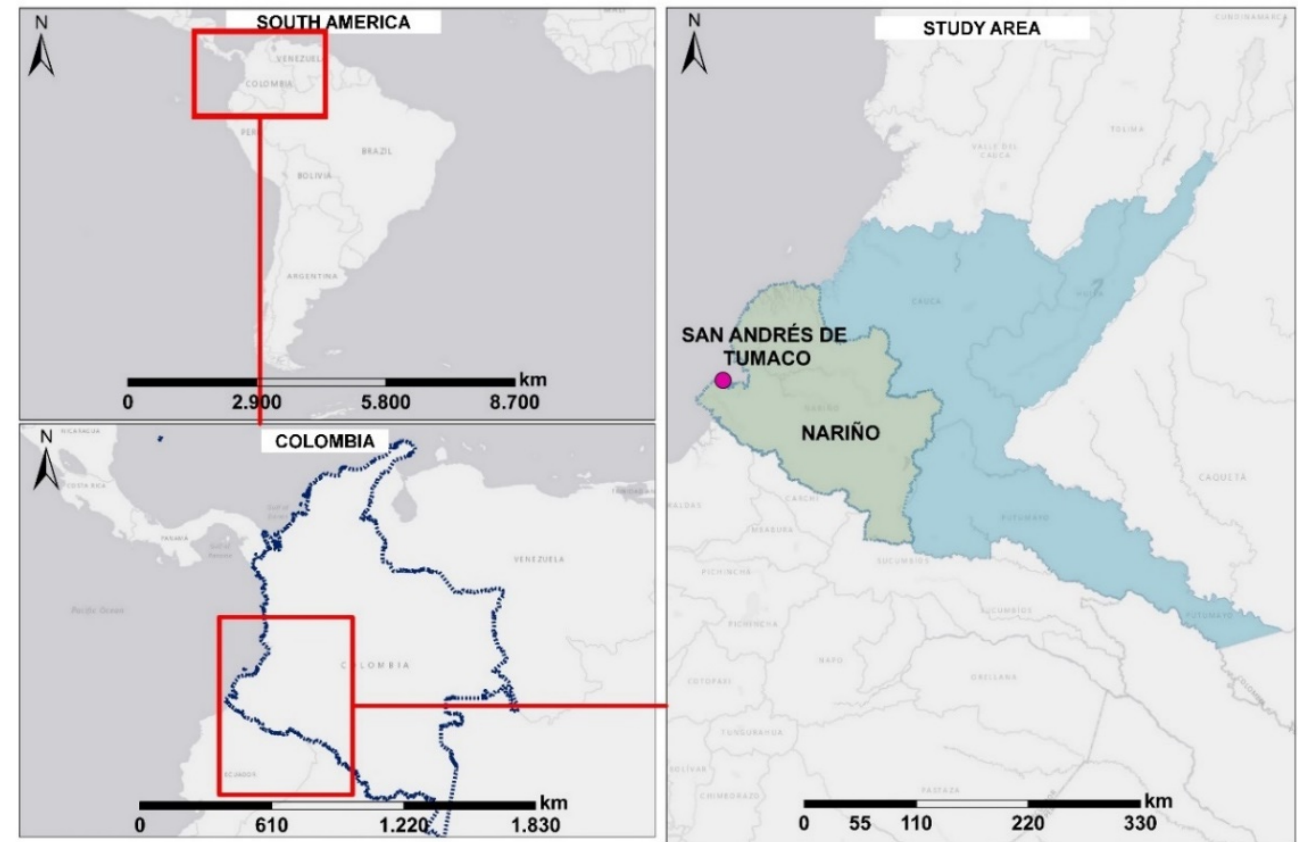

Fig. 1 - Location of the municipality of San Andrés de Tumaco Source: the authors 
Analysis of Road Intervention Based on Geographical Accessibility

as a Development Tool in Regional Competitiveness

\section{Collection of basic information and digital structures}

The approached research methodology is made up of a total of seven fractions, being a fundamental part of the process (Fig. 2).

As the first methodological fraction, we proceed to exhaustively investigate the existing digital databases to obtain the shape-type digital structures of each municipality, department, and region. Thus, it is possible to obtain the road infrastructure network based on the study, extracted from the DANE geoportal (DANE 2020), as well as the distribution by municipalities. Additionally, we proceed to inquire about the participation of each municipality within the economy of the country to select the most important municipalities in the area. Next, the existing information regarding transportation costs is located (Colombian Ministry of Transport 2019a).

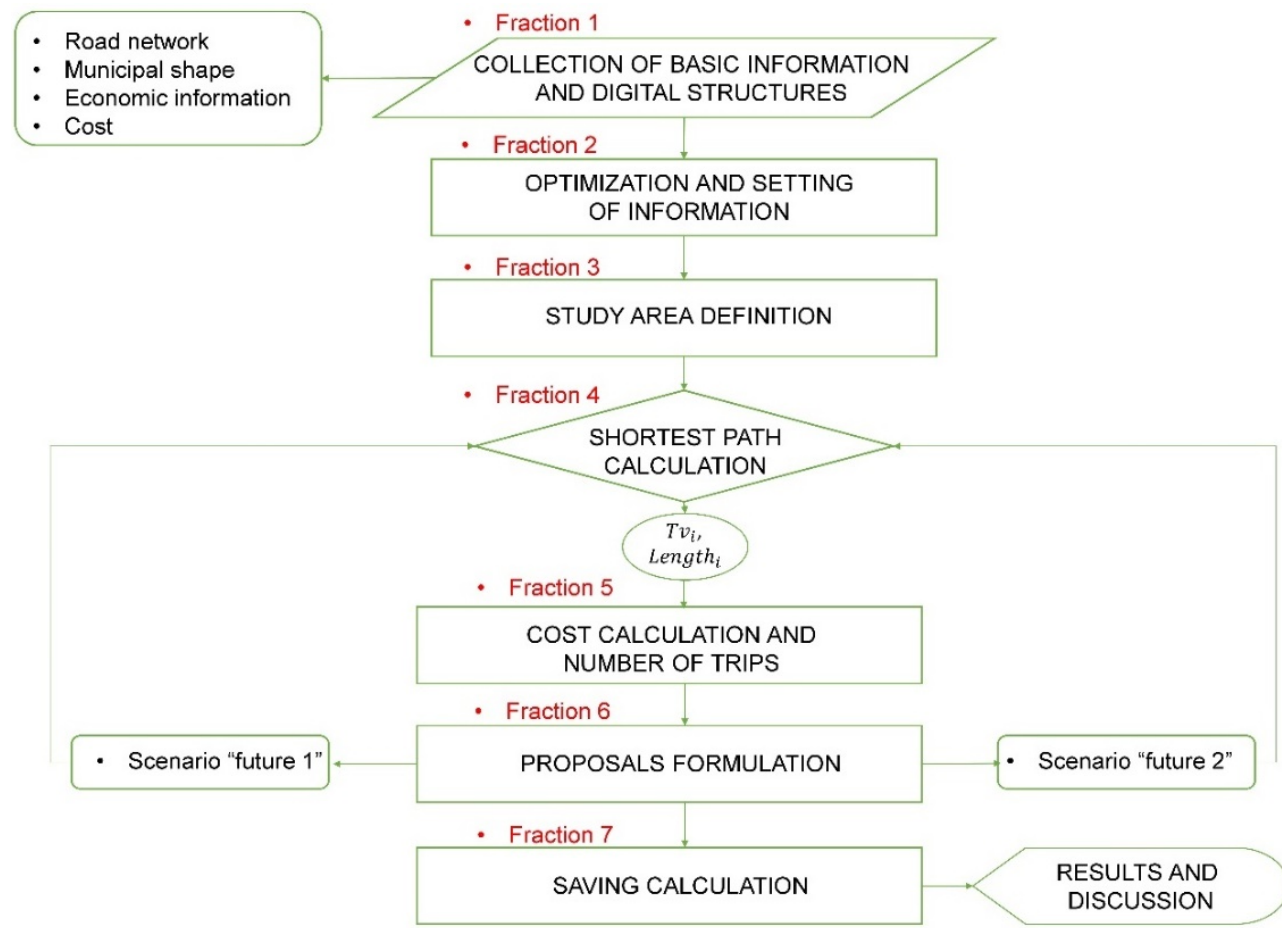

Fig. 1 - Research methodology

Source: the authors

Optimization and the setting of information

Once the base information has been obtained from the existing sources, the optimization of each of the acquired elements is carried out. In the first instance, an audit of the road infrastructure network is made to observe the possible disconnections and the absence of fragments. This process is carried out by using the topology tool in the ArcMap program. This audit contemplates the evaluation of the disconnected links, the directionality of the roads, the corroboration of the speed, and the location of the municipalities (Fig. 3). Subsequently, the information associated with the municipal estates is reviewed, as well as the data referring to basic transportation costs. Fig. 4 shows the digital base information to be used (road network, municipalities). 


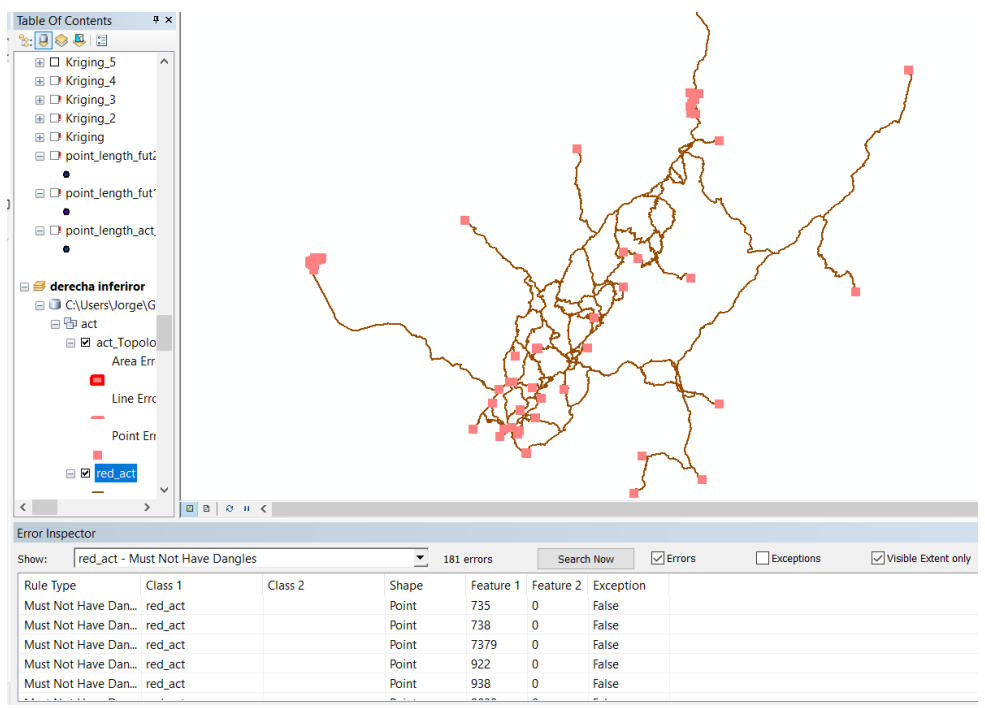

Fig. 3 - Topology intervention Source: the authors

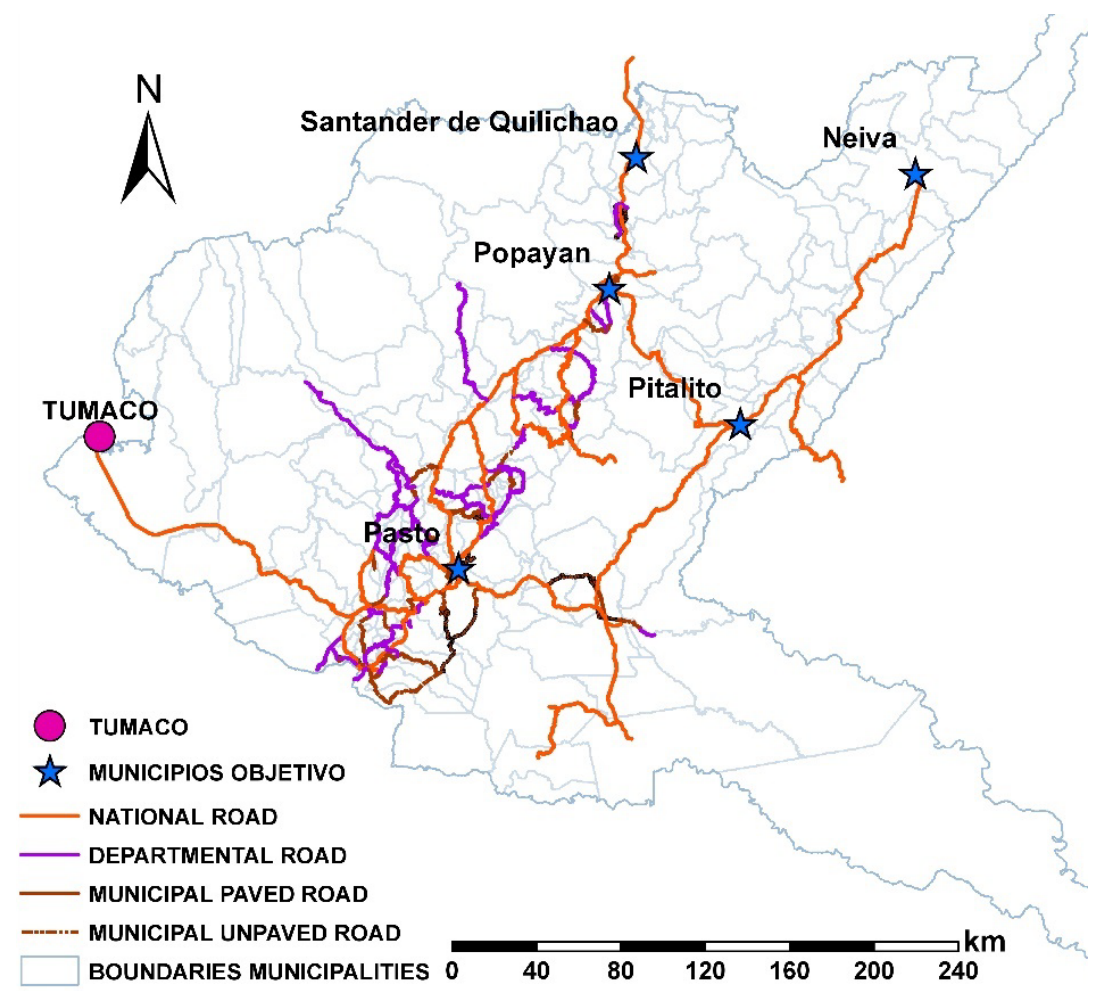

Fig. 4 - Information calculation base

Source: the authors, using the DANE base information 


\section{Study area definition}

Taking into account that the research process presented is part of the results of a larger project, it is decided to define the study area based on the macro-region formed by the neighbouring departments of the Nariño department, which contains the municipality of San Andrés de Tumaco, the centre of development of this research. Likewise, the area is subdivided by municipalities, limiting to those municipalities that have a direct relationship with the road infrastructure to be used.

\section{Shortest path calculation}

As a previous requirement, we proceed to select the target municipalities of greater regional importance. The process consists of filtering and ordering the information regarding the added value and the importance index obtained from the official bases of DANE (2019). From the defined study area, the municipalities with the best ranking, concerning the departmental and national contribution, are selected as areas of higher productivity, with 1 being the best rating and 7 being the least favourable condition (DANE 2019). Considering the above, it is obtained that in the study area the best rating is referred by 5 municipalities with an importance rating of 2. These are: San Juan de Pasto, Santander de Quilichao, Popayán, Neiva, and Pitalito. In Table 1, the assessment of the selected municipalities is appreciated, as well as the rating of the municipality of San Andrés de Tumaco, the central focus of this research.

Table 1

Municipalities with the highest importance rating

\begin{tabular}{|c|c|c|c|c|}
\hline Department & $\begin{array}{c}\text { Municipality } \\
\text { code }\end{array}$ & Municipality & $\begin{array}{c}\text { Added value } \\
\text { (Billions of Dollars) }\end{array}$ & $\begin{array}{c}\text { Degree of } \\
\text { economic } \\
\text { importance }\end{array}$ \\
\hline Cauca & 19001 & Popayán & 204.96 & 2 \\
\hline Cauca & 19698 & Santander de Quilichao & 75.40 & 2 \\
\hline Huila & 41001 & Neiva & 263.49 & 2 \\
\hline Huila & 41551 & Pitalito & 76.27 & 2 \\
\hline Nariño & 52001 & Pasto & 258.05 & 2 \\
\hline Nariño & 52835 & San Andrés de Tumaco & 6577 & 3 \\
\hline
\end{tabular}

Source: the authors

After selecting the target municipalities and optimizing the road network, the time and distance vectors are calculated considering the use of travel time (Eq. 1) of each road section as an impedance variable. The procedure is based on Dijkstra's shortest path algorithm, which was developed in 1959 (Dijkstra 1959) contemplating the use of the graph theory (Biggs et al. 1986), where the shortest path is obtained from the traffic conditions defined in the network (Makariye 2017). Thus, the shortest path from each node of the network to the target municipalities is selected (Eq. 2). Once the shortest path concerning the travel time has been obtained, the final length of the route to be taken is determined (Eq. $3)$.

$$
T v_{k}=\frac{\text { length }_{k}(\mathrm{~km})}{\operatorname{speed}_{k}\left(\frac{\mathrm{km}}{\mathrm{h}}\right)}
$$


Where $T v_{k}$ is the travel time of arc $k$, obtained from the division between the length and speed of each arc.

$$
\begin{gathered}
T v_{i}=\min \left(T v_{i j}\right), \\
j=1: n, T v_{i j}=\min \left\{T v_{i j_{1}}, T v_{i j_{2}}, \ldots, T v_{i j_{m}}\right\}, m=\text { Roads }
\end{gathered}
$$

Where $T v_{i}$ is the travel time from node $i$ to the nearest target municipality; $T v_{i j}$ is the shortest of the travel times from node $i$ to municipality $j$, within the set of values $T v_{i j m}$ obtained from the Dijkstra's algorithm. In order to give greater clarity to the calculation of the minimum time of each node, Fig. 5 is presented.

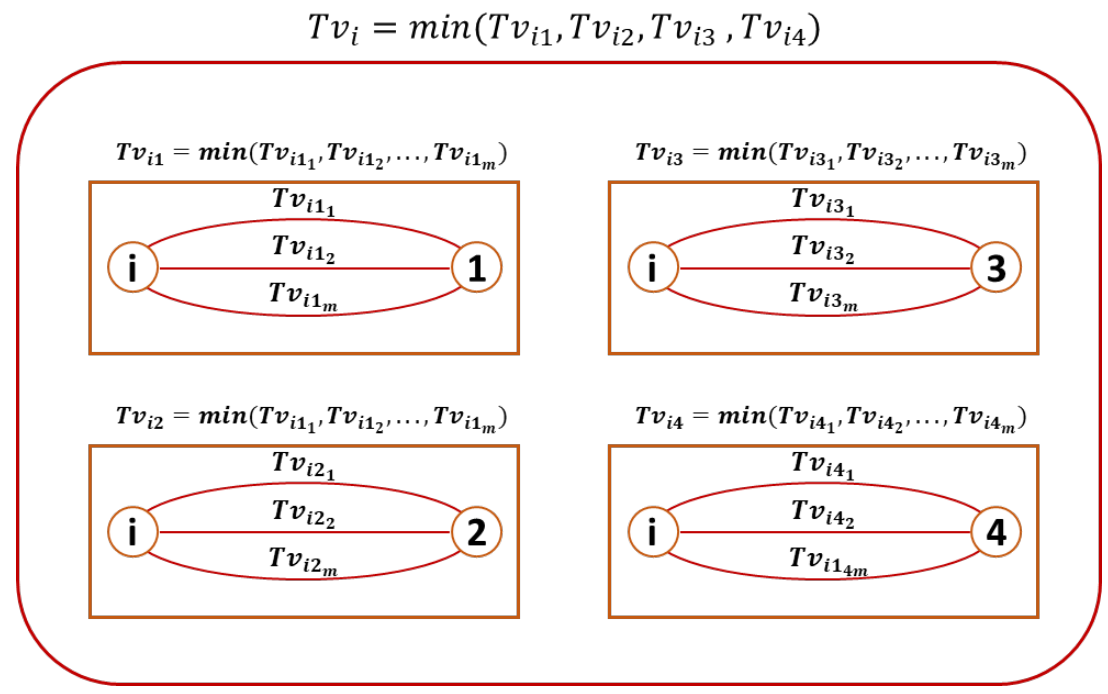

Fig. 5 - Minimum travel time to the nearest main city

Source: the authors

$$
\text { Length }_{i}=\sum_{k=1}^{n} \text { length }_{k}, \quad k \in\left\{\text { arcs on the road } T v_{i}\right\}
$$

Where Length $_{i}$ is the sum of the lengths of $\operatorname{arcs} k$, from node $i$ to the nearest target municipality, from the time $T v_{i}$ obtained.

From the same structure, the average time and length of each node in the network, for the set of target municipalities, is obtained through Eq. 4 and 5 , where $\bar{T}_{i}$ is the average of the minimum travel times from node $i$ to each municipality $j ; \overline{L_{e n g t h}}$ is the average length of node $i$, obtained from the minimum lengths for each $T v_{i j}$.

$$
\begin{aligned}
& T v_{\text {promi }}=\operatorname{prom}\left(T T v_{i j}\right) \\
& j=1: n, T v_{i j}=\min \left\{T v_{i j_{1}}, T v_{i j_{2}}, \ldots, T v_{i j_{m}}\right\}, m=\text { Roads } \\
& \text { Length }_{\text {prom } i}=\operatorname{prom}\left(\text { Length }_{i j}\right) \rightarrow \text { Length }_{i j}=\sum_{k=1}^{n} \text { length }_{k} \text {, } \\
& k \in\left\{\operatorname{arcs} \text { on the road } T v_{i j}\right\}
\end{aligned}
$$


Analysis of Road Intervention Based on Geographical Accessibility

as a Development Tool in Regional Competitiveness

\section{Cost calculation and the number of trips}

Carrying on with the methodological development, we proceed to determine the cost per ton and the number of possible trips. In this sense, we begin to determine the base cost per kilometre to be used, which is obtained from the division between the cost of transportation between cities for a 2-axle truck-type vehicle (Colombian Ministry of Transport 2019a) and the distance to travel, obtained from the SICE-TAC platform (Colombian Ministry of Transport 2020). In this way, an average transportation cost per ton-kilometre of 311.43 Colombian pesos is obtained, with a variation of \pm 34.11 pesos. Next, the value obtained from the minimum and average lengths is multiplied for each scenario by the base cost of transportation.

On the other hand, the calculation of the number of trips takes its base value, based on the number of working hours of operation in the month (288 hours) obtained from the SICE-TAC platform (Colombian Ministry of Transport 2020). It is important to highlight that the value presented does not include the times of loading and unloading. Therefore, the number of final trips may be affected depending on the items to be transported. Hence, the number of possible trips to the nearest municipality and the set of municipalities is obtained by dividing the calculated travel time in each scenario by 288 business hours in a month.

\section{Proposals' formulation}

Once the procedure to calculate the costs and the number of trips in the study area have been defined, pertinent interventions are made, establishing two scenarios; scenario Future 1 , which studies the geometric correction of the corridor and the repaving of the surface in 184.13 kilometres to increase the operational speed to $51 \mathrm{~km} / \mathrm{h}$; and scenario Future 2, which considers the construction of a new 83.57-kilometer road corridor between El Pailón and La Llanada. Additionally, the fact that scenario Future 2 links the carried-out interventions in scenario 1 is highlighted, in order to link the interventions as a phased intervention plan. This considers an operational speed of $51 \mathrm{~km} / \mathrm{h}$, while in Fig. 6 , the intervention bands for the scenarios are shown.

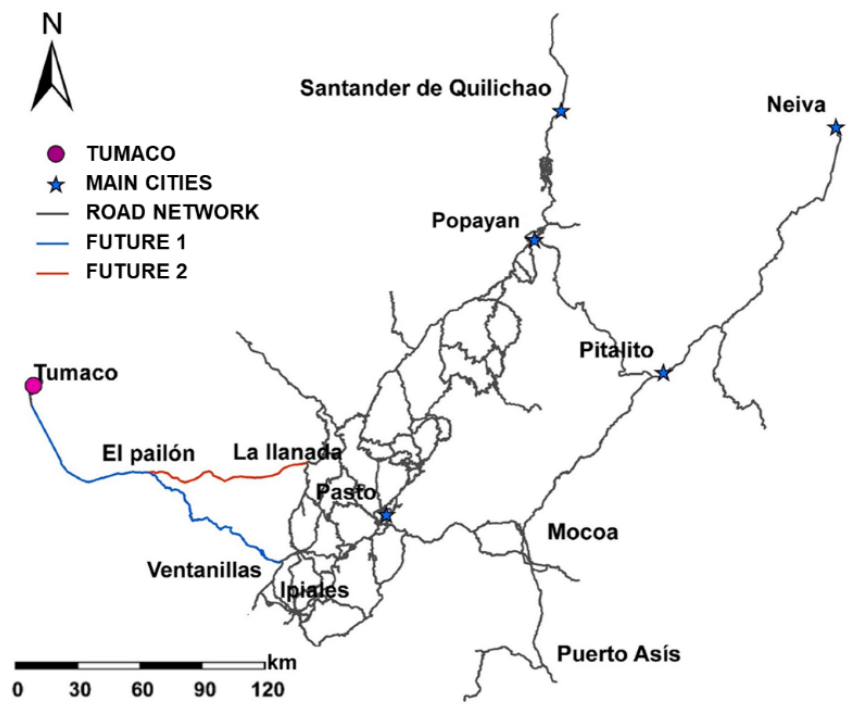

Fig. 6 - Intervention scenarios

Source: the authors 


\section{Saving calculation}

Once the different scenarios have been evaluated, it is necessary to calculate the saving percentage generated by the interventions which is made from equation 6 , where Saving $s_{i}$ will be the ones perceived in node $i$, obtained from the difference between the future value $V . F u t_{i}$ in each scenario and the current value $V$. Act $_{i}$.

$$
\text { Savings }_{i}=\left(1-\frac{\left(V \cdot F u t_{i}\right)}{V \cdot \text { Act }_{i}}\right) * 100 \%
$$

\section{Results and Discussion}

As a result of the cost analysis and the number of trips to the municipalities of greatest national importance in the region, we further highlight the behaviour associated with each of the analyzed scenarios.

The cost of transport behaviour per ton to the nearest municipality, within the group of most important municipalities, is clear in the 3 scenarios discussed (Fig. 7). The highest transport costs within the region are presented in the municipality of San Andrés de Tumaco, taking into account that it has only one access road (the current situation), which must support all traffic entering and leaving the municipality. Likewise, there is no variation between the different scenarios, since, despite the interventions in the speed and the construction of the road, the travelled distance to the nearest main municipality does not vary, so that the maximum cost ranges observed reach 90000 to 95000 Colombian pesos (23.32 to 24.62 USD). On the other hand, it is understood that the lower transport costs, which are less than 10,000 Cop (2.59 USD), refer to the urban transport or to very close areas to the main municipalities, so they would not have a direct impact on the mobilization of cargo in the region.

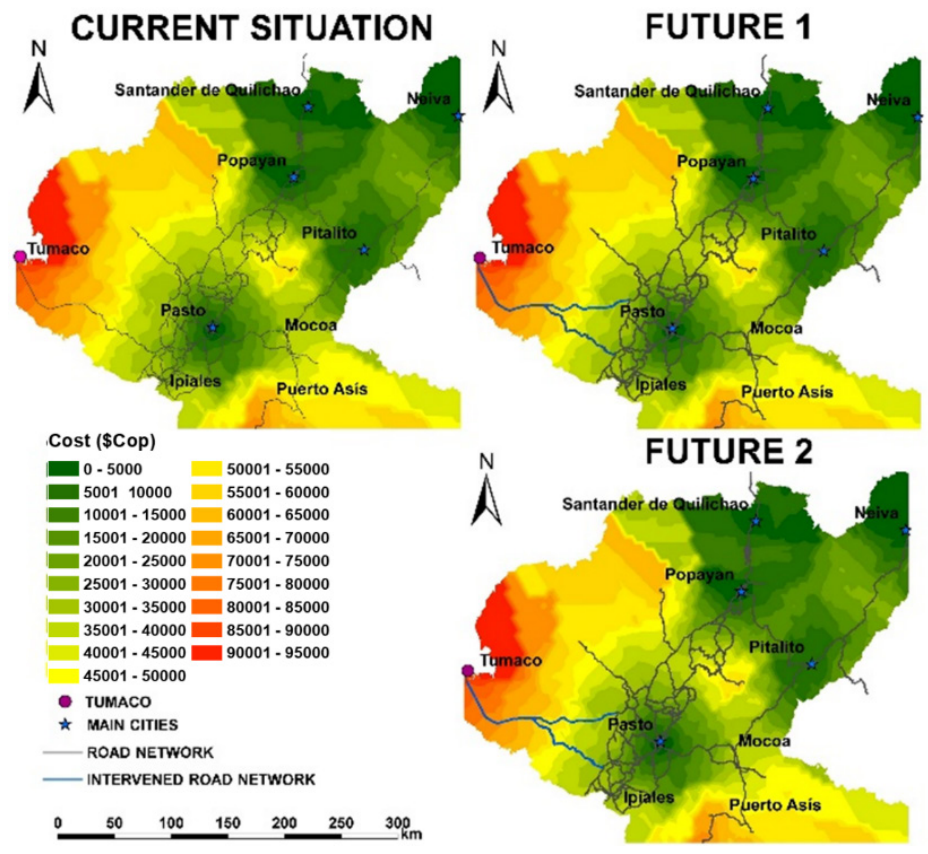

Fig. 7 - Transportation cost per ton to the nearest major municipality in each scenario Source: the authors 
The average cost obtained for the group of municipalities of greatest national importance in the region (Fig. 8) considers the average joint displacement to the 5 municipalities, from which a maximum average value of between 1650,000 and 175,000 Cop (42.75 and 45.34 USD) per ton is obtained. It is possible to show that in each of the proposed scenarios, the highest cost is presented in the area of the municipality of San Andrés de Tumaco. However, there is a decrease in the cost for future scenario 2, in which the maximum cost ranges between 150000 and 155000 (38.86 to 40.16 USD).
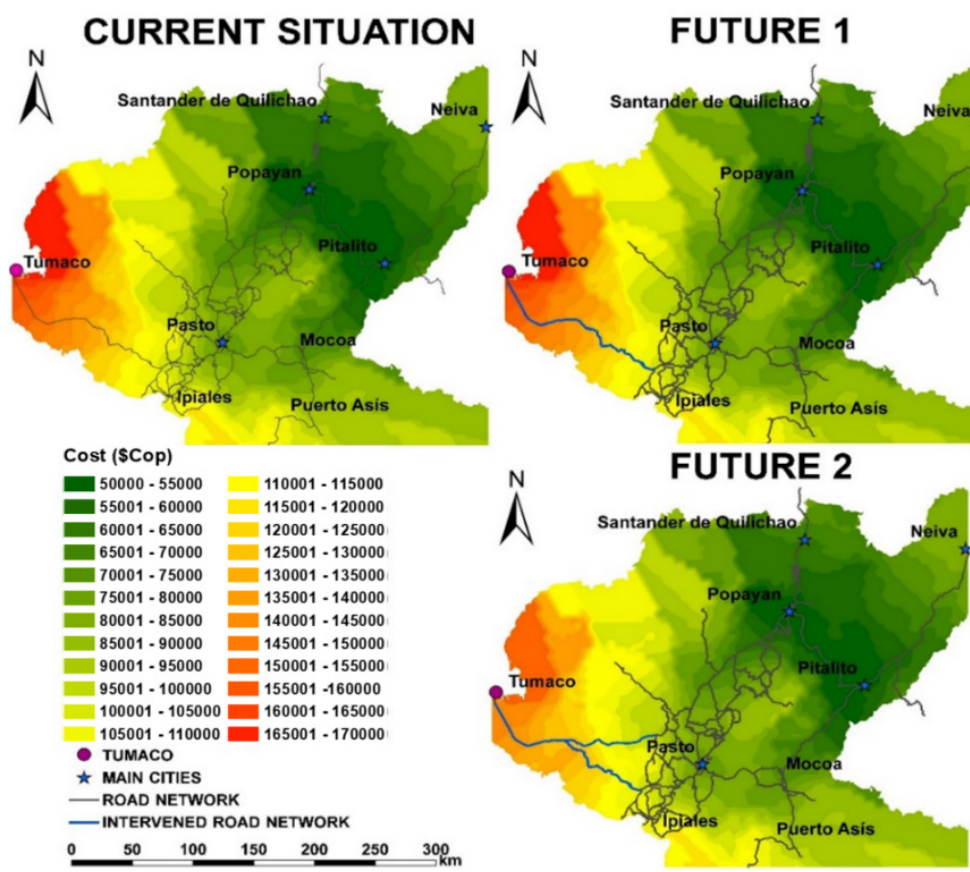

Fig. 8 - Average cost of transport per ton to the most important municipalities in the region

Source: the authors

Carrying on with the presentation of results, the numbers of possible trips within the 288hour monthly working range obtained from the SICE-TAC platform are presented (Colombian Ministry of Transport 2020). On the number of simple trips (one-way) to the nearest main municipality (Fig. 9), it is observed that the south-western part of the region has the least possibility of trips concerning the monthly working hours, reaching its lowest value between 40 to 50 trips per month. On the other hand, the north-eastern area presents the greatest ease of travel due to the higher concentration of municipalities of greater importance. Likewise, it is considered that more than 290 trips per month are classified as urban, so the incidence in the region is not significant. Similarly, the variation between scenarios is not quite observable. However, there is a reduction in the area of action of the curves between 40 to 70 trips per month on the road under intervention.

Referring to the variation in the average monthly trips to all the most important municipalities in the region (Fig. 10), the highest number of possible trips is presented for the northeast sector (75-77.5 trips), and the lowest for the southwest sector, with values between 22.5 and 25 trips per month. The variation observed between the scenarios is subtle, minimizing the area of action of the curves from 25 to 30 trips per month, between the future scenarios 1 and 2 , both cases being in the vicinity of the municipality of San Andrés de Tumaco. 

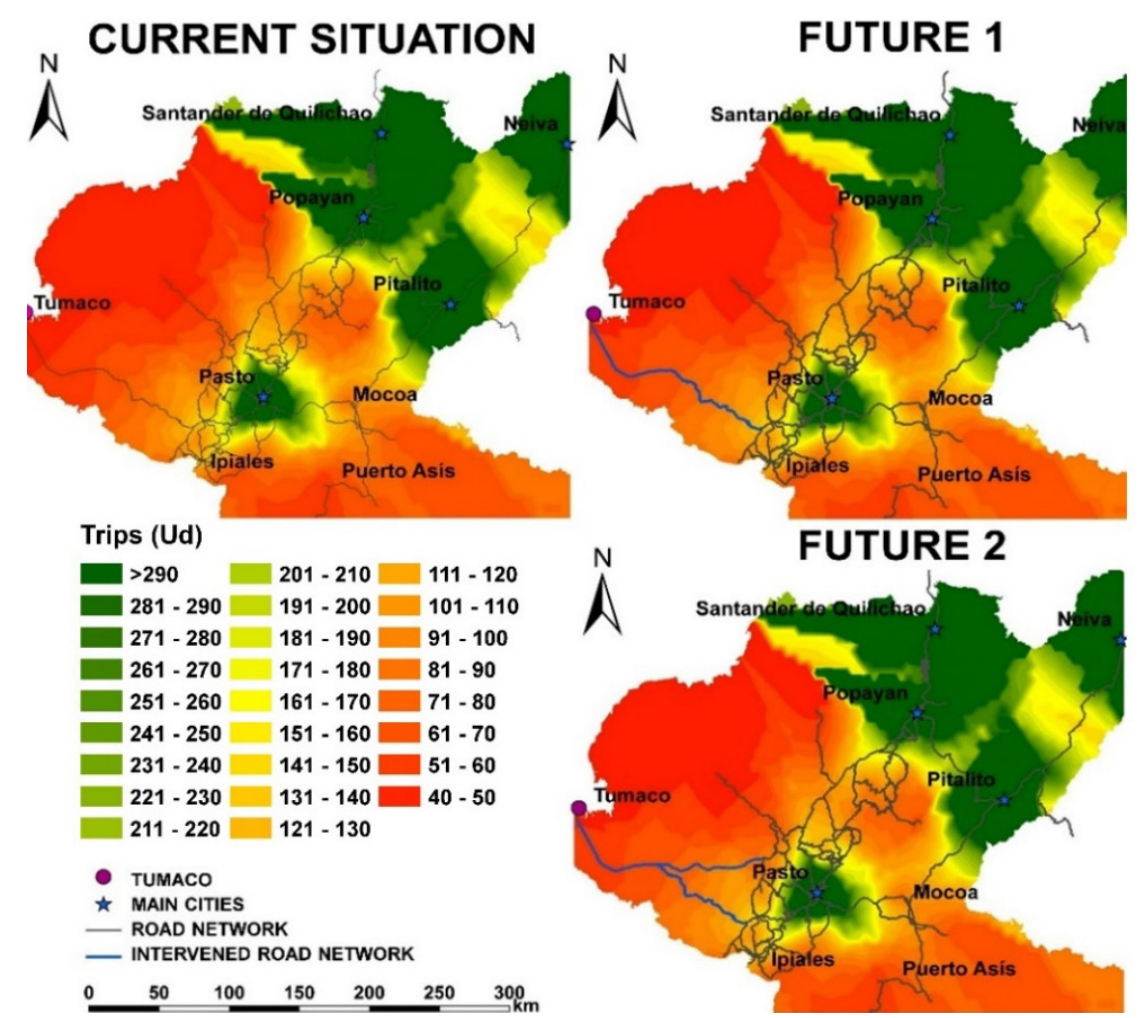

Fig. 9 - Number of possible trips per month to the nearest major municipality Source: the authors

Table 2 shows a summary of the cost behaviour and the number of trips for each proposed scenario in the municipality of San Andrés de Tumaco, taking into account that the purpose of the research is to evaluate an alternative for connectivity, such as improving the development of the municipality. Thus, the first column shows that the cost per ton transported to the nearest major city, in this case, San Juan de Paso, does not vary. This is due to the improvement in the speed of the network, as well as the fact that the construction of the new road does not affect the distance between the municipality of San Andrés de Tumaco and San Juan de Pasto. However, it leaves open a new possibility of connection in the event of possible closures on the main road. On the other hand, the average cost of transport per ton to all the main cities does not vary in the future in comparison with the current scenario 1. This is because although the speed of operation of the road increases, the travelled distance is the same. Despite this, there is a reduction in the cost of transport per ton - 12,400 COP (3.23 USD), including the new road - because this new corridor allows more efficient connectivity within the cities in the northern sector, as well as it is facilitating the movement towards the interior of the country.

By continuing with column 3 , referring to the number of trips to the nearest major city and starting from the base of the 288-working-hour per month (Colombian Ministry of Transport 2020), the result is that the number of trips, currently possible between the municipality of San Andrés de Tumaco and San Juan de Pasto, is approximately of 42 trips or 21 complete cycles. After the intervention, a total of 46 trips were made, i.e. 23 complete cycles, which gives an increase of 4 trips per vehicle to the nearest city. This could result in a net gain for the transport of around 360000 Cop (93.27 USD) per vehicle, equivalent to $36.33 \%$ of the current legal minimum wage. 

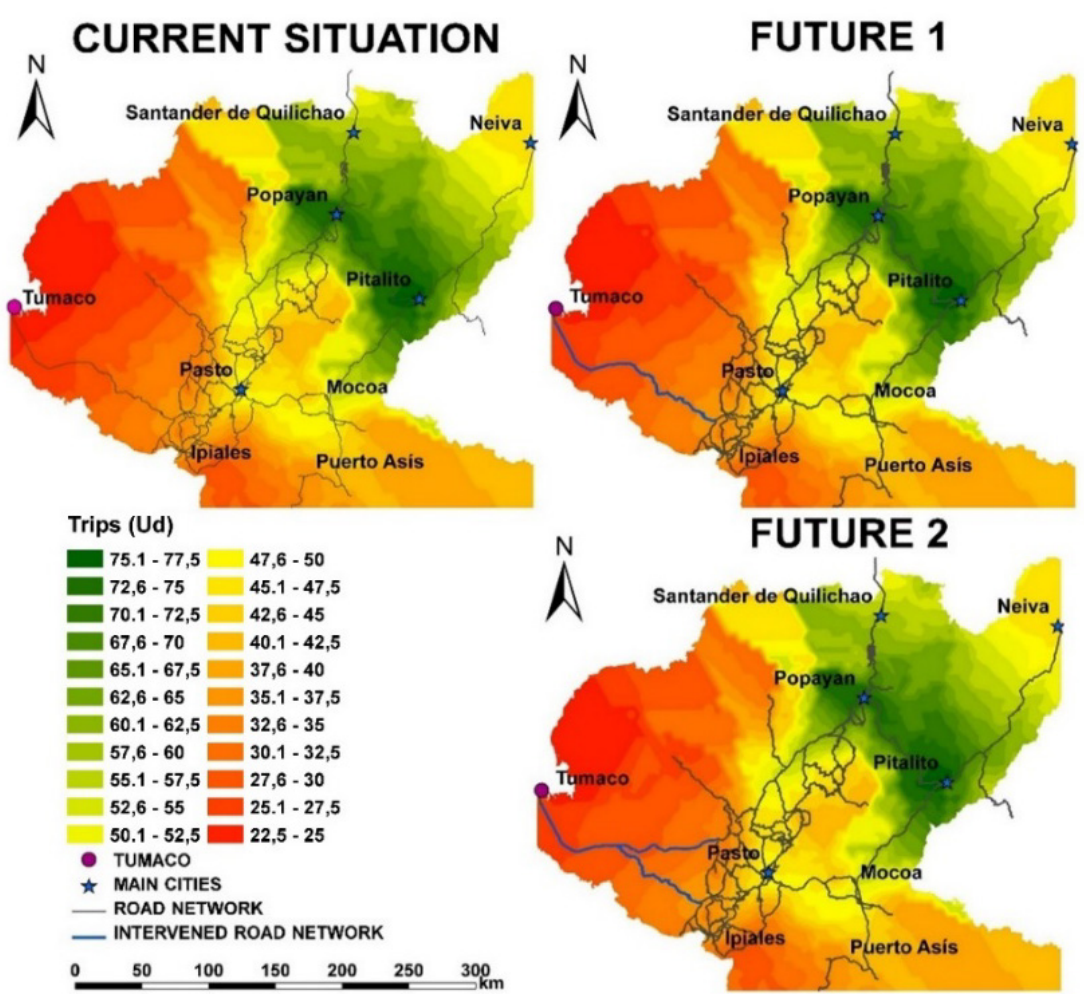

Fig. 10 - Average number of possible trips per month to the set of municipalities of greatest national importance within the region

Source: the authors

Finally, column 4 shows the variation of average trips to the main cities in the region. For the current situation, there is an average of 23.16 trips, starting from Tumaco, going to a total of 24.42 trips in intervention 1 and 24.55 trips in intervention 2. Thus, when comparing the average cost and the increase in trips, a benefit of 206302 USD and 245794 USD (53.45 and 63.68 USD) per vehicle is achieved in each scenario, respectively.

Table 1

Variation of costs and trips for each scenario in the municipality of San Andrés de Tumaco

\begin{tabular}{|c|c|c|c|c|}
\hline Scenario & $\begin{array}{c}\text { Cost per ton to } \\
\text { the nearest } \\
\text { main city } \\
\text { Cop (USD) }\end{array}$ & $\begin{array}{c}\text { Average cost per } \\
\text { ton to the set of } \\
\text { main cities } \\
\text { Cop (USD) }\end{array}$ & $\begin{array}{c}\text { Number of } \\
\text { trips to the } \\
\text { nearest main } \\
\text { city (trip) }\end{array}$ & $\begin{array}{c}\text { Average number } \\
\text { of trips to the set } \\
\text { of main cities } \\
\text { (trip) }\end{array}$ \\
\hline Current & $89072(23.08)$ & $164655(42.66)$ & 41.88 & 23.16 \\
\hline Future 1 & $89072(23.08)$ & $164655(42.66)$ & 46.17 & 24.42 \\
\hline Future 2 & $89072(23.08)$ & $52249(39.45)$ & 46.17 & 24.55 \\
\hline
\end{tabular}

Source: the authors 
On the percentage of cost savings for the nearest municipality (Fig. 11), the road intervention proposed for future scenario 1 and future scenario 2 has no impact on the costs. Likewise, on the average cost saving behaviour towards all municipalities (Fig. 12), the road intervention in future scenario 1 does not generate a reduction in transportation costs, but the road intervention in future scenario 2 does achieve reductions of up to $8 \%$.

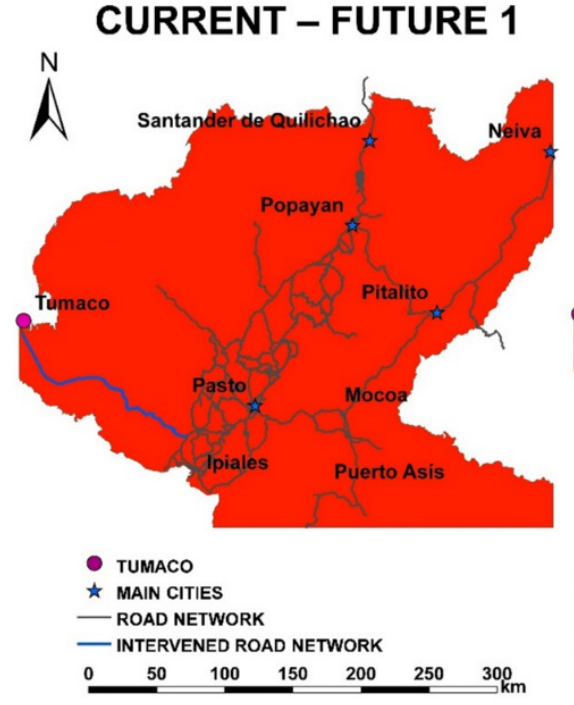

\section{CURRENT - FUTURE 2}

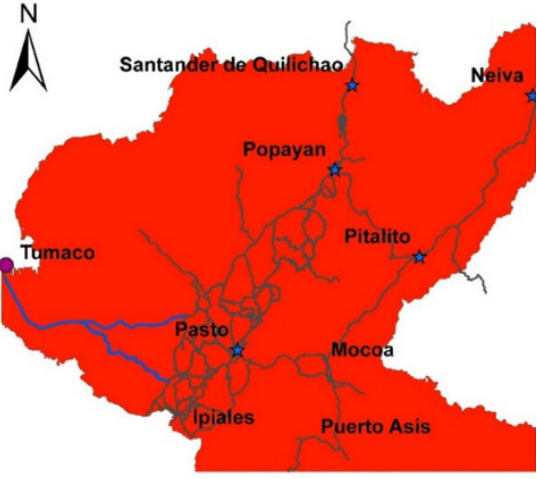

Saving (\%)

0 - $1 \quad 4.1-5 \square 8.1-9$

\begin{tabular}{l|l}
$1.1-2 \square$ & $5.1-6 \square 9.1-10$
\end{tabular}

$\begin{array}{lll}2.1-3 & 6.1-7 & 10.1-11\end{array}$

$3.1-4=7.1-8$

Fig. 11 - Cost savings per ton to the nearest major municipality Source: the authors

\section{CURRENT - FUTURE 1}

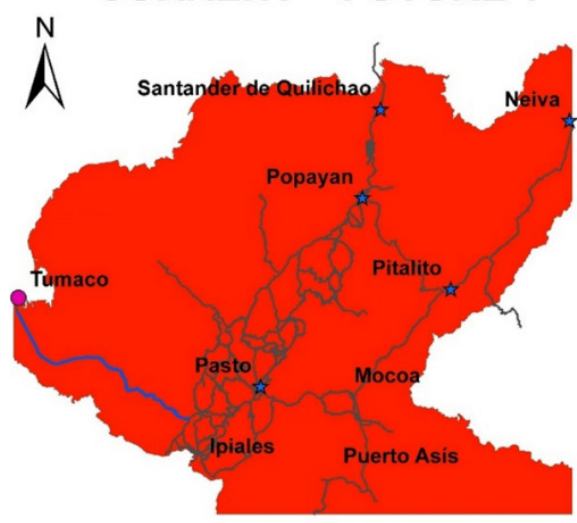

- tUMACO

$\star$ MAIN CITIES

- ROAD NETWORK

- INTERVENED ROAD NETWORK

$\begin{array}{lllll}0 & 50 & 100 & 150 & 200\end{array}$

\section{CURRENT - FUTURE 2}

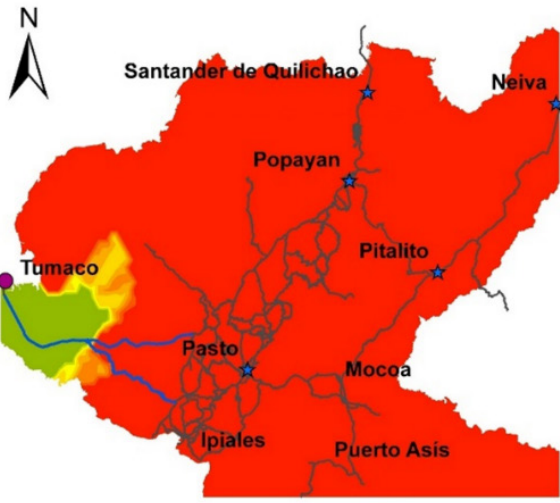

Saving (\%)

$\begin{array}{lll}0-1 & 4.1-5 & 8.1-9\end{array}$

\begin{tabular}{ll|l}
$1.1-2$ & $5.1-6$ & $9.1-10$
\end{tabular}

\begin{tabular}{ll|l}
$2.1-3$ & $6.1-7$ & $10.1-11$
\end{tabular}

\begin{tabular}{ll}
$-1.1-4 \square 7.1-8$ \\
\hline
\end{tabular}

Fig. 12 - Average cost savings per ton for the most important set of municipalities in the region

Source: the authors 
Given the savings behaviour in the number of trips for the region in each evaluation scenario (Fig. 13), the intervention of future scenario 1 generates savings of up to $11 \%$ in the Southwest area. Likewise, the construction of the new road in future scenario 2 has no impact on the number of journeys to the nearest town because the recovery and improvement of the road in future scenario 1 mean a reduction in time and number of journeys. In the case of the average number of journeys, the road intervention in future scenario 1 has a significant impact of up to $5 \%$ on the average number of journeys (Fig. 14). However, when road intervention is carried out in future scenario 2, this percentage of savings increases to $6 \%$, generating a joint improvement if the savings in costs and the number of journeys are considered.

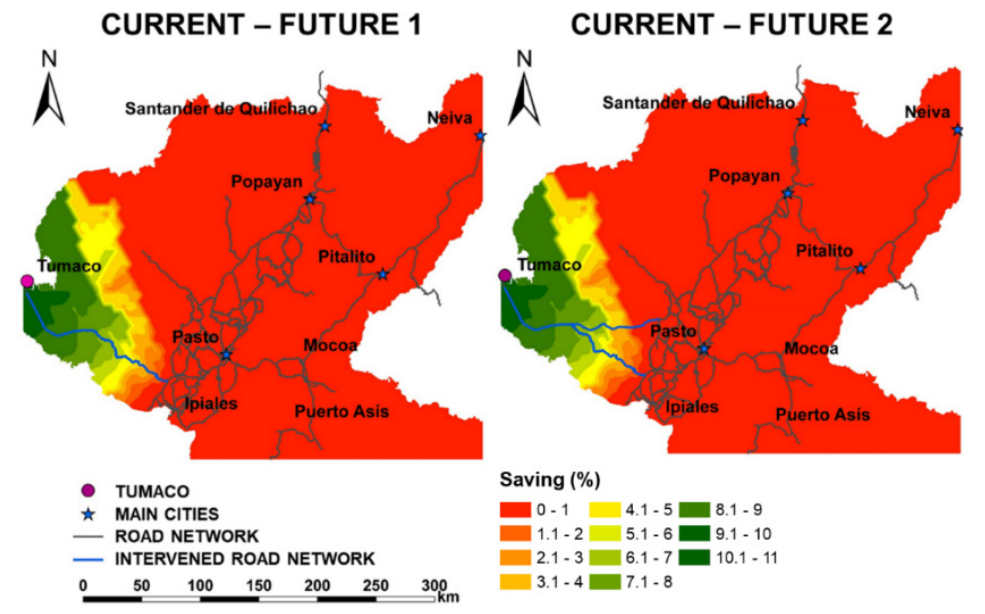

Fig. 13 - Savings in the number of trips to the nearest main municipality Source: the authors

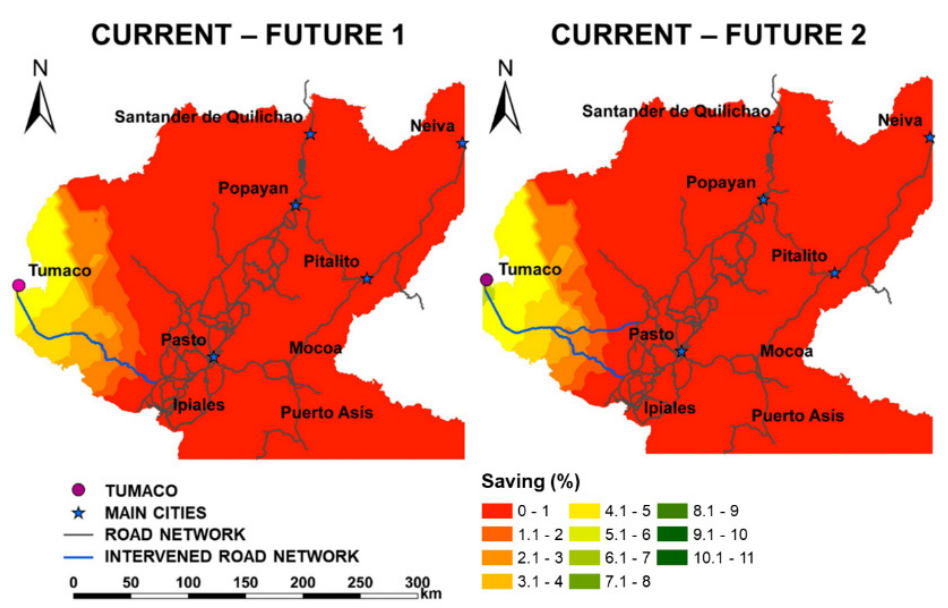

Fig. 14 - Savings in the average number of trips to the set of most important municipalities in the region

Source: the authors 
Table 3 shows the percentage of savings for the proposed scenarios. In the first column, it is observed that there is no variation in the costs per ton transported to the nearest city for each intervention scenario. However, the perceived savings in the average cost for the main cities is up to $7.53 \%$. On the other hand, the variation in the number of trips shows a saving of up to $10.23 \%$ to the nearest city and $5.99 \%$ to the set of main cities; there are significant percentages if it is considered that the assessment is made per vehicle and per ton.

Savings in costs and trips for each scenario

Table 3

\section{in the municipality of San Andrés de Tumaco}

\begin{tabular}{|c|c|c|c|c|}
\hline Scenario & $\begin{array}{c}\text { Saving cost } \\
\text { per ton to the } \\
\text { nearest main } \\
\text { city } \\
\mathbf{( \% )}\end{array}$ & $\begin{array}{c}\text { Savings in the } \\
\text { average cost per } \\
\text { ton to the set of } \\
\text { main cities } \\
\mathbf{( \% )}\end{array}$ & $\begin{array}{c}\text { Increase in the } \\
\text { number of trips } \\
\text { to the nearest } \\
\text { main city } \\
\mathbf{( \% )}\end{array}$ & $\begin{array}{c}\text { Average } \\
\text { number of } \\
\text { travels to the } \\
\text { set of main } \\
\text { cities } \\
(\%)\end{array}$ \\
\hline Current vs future 1 & $0.00 \%$ & $0.00 \%$ & $10.23 \%$ & $5.41 \%$ \\
\hline Current vs future 2 & $0.00 \%$ & $7.53 \%$ & $10.23 \%$ & $5.99 \%$ \\
\hline
\end{tabular}

Source: the authors

Taking into account the impact generated by the intervention proposals, it is possible to demonstrate that the model of evaluation of accessibility allows giving greater clarity as far as the zones with greater benefit, giving an additional perspective to the traditional models of evaluation (De Dios Ortúzar and Willumsen 2011). On the other hand, the observed savings can be significant concerning the scale of work, bearing in mind some evaluations carried out in other cities and regions of the country, in which the impact evaluation is similar, in a smaller study area (Sarmiento Ordosgoitia et al. 2000, Escobar et al. 2018a, Escobar et al. 2018b).

As a final discussion, it is possible to express that the road intervention proposed in scenario number 1 only creates an impact on the number of possible trips. Taking that into consideration, since the length of the trip does not vary, the cost per ton does not have a reduction or increase concerning the current situation. Despite this, the increase in the number of trips makes it possible for the municipality to be more active within the region, as it allows for the mobilization of more products and inputs needed for the economic development of the municipality. On the other hand, scenario 2 generates significant impacts on the cost and number of trips. This impact makes it possible to speed up the municipality's marketing dynamics by guaranteeing a new connection corridor with the other members of the region.

Impact assessments should therefore be carried out at national level in order to establish the final impact on road construction (Table 4). On the other hand, an analysis of construction and intervention costs should be carried out to quantify the amount needed for the project development. However, they have an approximate average value per kilometre built of 19,033 million Colombian pesos, obtained from the projects already implemented in the nation (Colombian Ministry of Transport 2019b). It is important to consider that the percentage of impact is associated with the transport of 1 ton per kilometre, but the traffic in the area includes the operation of trucks of around 10 tons per vehicle and the latest flow of cargo vehicles recorded by INVIAS (2011) is 436 vehicles per day. With these values, as well as the difference in the cost of the intervention, a monthly value of $442,582.85$ USD can be estimated, which is an important value to be considered in regional competitiveness. 


\begin{tabular}{|c|c|c|c|c|c|c|}
\hline Scenario & $\begin{array}{c}\text { Ton per } \\
\text { vehicle }\end{array}$ & $\begin{array}{c}\text { Cargo } \\
\text { vehicle } \\
\text { flow }\end{array}$ & $\begin{array}{c}\text { Savings in } \\
\text { average cost } \\
\text { per ton to the } \\
\text { set of main } \\
\text { cities (7.53 \%) }\end{array}$ & $\begin{array}{c}\text { Average } \\
\text { number of } \\
\text { travels to } \\
\text { the set of } \\
\text { main cities } \\
(\%)\end{array}$ & $\begin{array}{c}\text { Monthly } \\
\text { days }\end{array}$ & $\begin{array}{c}\text { Monthly } \\
\text { cost saving }\end{array}$ \\
\hline Saving cost & 10 & 436 & 3.21 USD & $5.41 \%$ & 30 & $\begin{array}{c}442582.85 \\
\text { USD }\end{array}$ \\
\hline
\end{tabular}

Source: the authors

\section{Conclusions}

It can be concluded, from the obtained results and observations, that the geographical accessibility models give a much broader vision of the impact generated by a road intervention, thus facilitating decision-making by the local administrations to focalize resources. Therefore, it is possible to argue that these types of analyses could be included in the constructive assessment of the projects to be executed.

In this sense, it would be prudent to make a more exhaustive analysis in terms of construction costs, as well as the addition of other variables in terms of calculating the global impact. This would allow for a more accurate assessment of the benefits of the intervention versus the construction costs.

Likewise, it can be seen that road intervention, whether in future scenario 1 or in future scenario 2, creates a significant impact on the transport dynamics only in the municipality of San Andrés de Tumaco, which allows to improve the conditions of competitiveness and to improve the connectivity of the municipality.

Despite this, some areas of the region with similar deficiencies to those of San Andrés de Tumaco are observed. In some cases, the sectors surrounding Tumaco, such as near Puerto Asís. Therefore, it would be prudent to carry out an individual analysis of these sectors to propose interventions that increase the equity connectivity in the region.

Finally, it can be clearly concluded that the current connectivity of the municipality of San Andrés de Tumaco shows great needs for a new connection route, which guarantees that, in a possible closure, the municipality would not be isolated because there is only one access route.

\section{References}

BIGGS N. L., LLOYD E. K., WILSON R. J. (1986), Graph Theory: 1736-1936, Oxford University Press, Oxford.

COLOMBIAN MINISTRY OF TRANSPORT (2019a), Costos de referencia por tonelada para un tractocamión (Reference costs per ton for a tractor unit), Retrieved from: www.mintransporte.gov.co.

COLOMBIAN MINISTRY OF TRANSPORT (2019b), Reporte proyectos ejecutados (Report of executed projects), Retrieved from: www.mintransporte.gov.co.

COLOMBIAN MINISTRY OF TRANSPORT (2020), Sistema de Información de Costos Eficientes para el Transporte Automotor de Carga SICE-TAC (Efficient Cost Information System for Automotive Freight Transportation SICE-TAC), Retrieved from: www.mintransporte.gov.co. 
CUI M., LEVINSON D. (2018), Full Cost Accessibility, Journal of Transport and Land Use $11(1), 661-679$.

CURL A., NELSON J. D., ANABLE J. (2011), Does accessibility planning address what matters? A review of current practice and practitioner perspectives, Research in Transportation Business \& Management 2, 3-11.

DANE (2018), Censo Nacional de Población y Vivienda (National Population and Housing Census), National Administrative Department of Statistics, Retrieved from: www.dane.gov.co.

DANE (2019), Indicador de importancia económica municipal (Municipal economic importance indicator), National Administrative Department of Statistics, Retrieved from: www.dane.gov.co.

DANE (2020), Marco geoestadistico nacional (National geostatistical framework) National Administrative Department of Statistics, Retrieved from: www.dane.gov.co.

DE DIOS ORTÚZAR J., WILLUMSEN L. G. (2011), Modelling transport, Wiley, Chichester.

DIJKSTRA E. W. (1959), A note on two problems in connexion with graphs, Numerische Mathematik 1, 269-271.

ELLDÉR E. (2014), Residential location and daily travel distances: the influence of trip purpose, Journal of Transport Geography 34, 121-130.

ESCOBAR D. A., MONTOYA GÓMEZ J. A., MONCADA C. A. (2018a), Evolution of Urban Accessibility in Manizales, Colombia, 2010 - 2017, Indian Journal of Science and Technology 11 (18), 1-11.

ESCOBAR D. A., MONTOYA J. A., MONCADA C. A. (2018b), Impact Assessment through Territorial Accessibility of the Set of Road Intervention Projects for the 2030 Skyline in the Municipality of Quibdo, Colombia, Indian Journal of Science and Technology 11 (29), $1-10$.

FUJITA M., KRUGMAN P., VENABLES A. J. (1999), The Spatial Economy: Cities, Regions, and International Trade, The MIT Press, Cambridge.

FUJITA M., THISSE J.-F. (2002), Economics of Agglomeration: Cities, Industrial Location, and Regional Growth, Cambridge University Press, Cambridge.

GEURS K. T., VAN WEE B. (2004), Accessibility evaluation of land-use and transport strategies: review and research directions, Journal of Transport Geography 12 (2), 127-140.

GRENGS J. (2015), Nonwork accessibility as a social equity indicator, International Journal of Sustainable Transportation 9 (1), 1-14.

HANDY S. L., NIEMEIER D. A. (1997), Measuring accessibility: an exploration of issues and alternatives, Environment and Planning A: Economy and Space 29 (7), 11751194.

HANSEN W. G. (1959), How Accessibility Shapes Land Use, Journal of the American Institute of Planners 25 (2), 73-76.

INGRAM D. R. (1971), The concept of accessibility: a search for an operational form Regional Studies 5 (2), 101-107.

INVIAS (2011), Flujo de vehículos de carga (Flow of cargo vehicles), National Roads Institute, Retrieved from: www.invias.gov.co.

KOTAVAARA O., ANTIKAINEN H., RUSANEN J. (2011), Population change and accessibility by road and rail networks: GIS and statistical approach to Finland 1970-2007, Journal of Transport Geography 19 (4), 926-935.

LI K. X., QI G. (2016), Transport connectivity and regional development in China Journal of International Logistics and Trade 14 (2), 142-155.

MAKARIYE N. (2017), Towards Shortest Path Computation using Dijkstra Algorithm, International Conference on loT and Application (ICIOT), 1-3.

MORRIS J. M., DUMBLE P. L., WIGAN M. R. (1979), Accessibility indicators for transport planning, Transportation Research Part A: General 13 (2), 91-109.

PIKE A., RODRÍGUEZ-POSE A., TOMANEY J. (2017), Local and regional development, Routledge, London. 
RUBULOTTA E., IGNACCOLO M., INTURRI G., ROFÈ Y. (2013), Accessibility and centrality for sustainable mobility: Regional planning case study, Journal of Urban Planning and Development 139 (2), 115-132.

SARMIENTO ORDOSGOITIA I., MUÑOZ RÍOS J. D., ÁNGEL SOTO C. A. (2000) Análisis de la Accesibilidad Vial en la Región del Occidente Colombiano, in: Colomer J. V. García A. (eds.), IV Congreso de Ingeniería del Transporte, Valencia, pp. 5-12.

SKOROBOGATOVA O., KUZMINA-MERLINO I. (2017), Transport Infrastructure Development Performance, Procedia Engineering 178, 319-329.

TUMACO DISTRICT MAYOR'S OFFICE (2017), Nuestro municipio, Retrieved from: www.tumaco-narino.gov.co.

VEGA A. (2011), A multi-modal approach to sustainable accessibility in Galway, Regional Insights 2 (2), 15-17.

VITALE BROVARONE E., COTELLA G. (2020), Improving Rural Accessibility: A Multilayer Approach, Sustainability 12 (7), 2876.

Initial submission: 09.06.2020

Revised submission: 19.10 .2020

Final acceptance: 23.12 .2020

Correspondence: Facultad de Ingeniería y Arquitectura, Departamento de Ingeniería Civil, Grupo de investigación en Movilidad Sostenible, Universidad Nacional de Colombia, Campus La Nubia, Bloque S2-208, Carrera 37 con Calle 94, Manizales, 170003, Columbia.

Email: joamontoyago@unal.edu.co 
